\title{
Small paleolakes of the Southern Kurils, as Holocene environmental archives
}

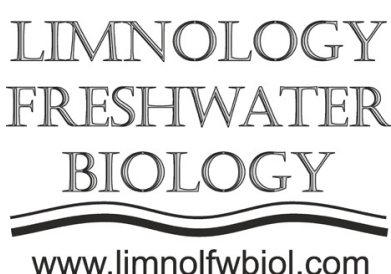

\author{
Razjigaeva N.G. ${ }^{1 *}$, Ganzey L.A. ${ }^{1}$, Grebennikova T.A. ${ }^{1}$, Nazarova L.B. ${ }^{2}$, \\ Mokhova L.M. ${ }^{1}$, Belyanina N.I. ${ }^{1}$, Arslanov Kh.A. ${ }^{3}$, Maksimov F.E. ${ }^{3}$, Petrov A.Yu. ${ }^{3}$, \\ Zazovskaya E.P. ${ }^{4}$ \\ ${ }^{1}$ Pacific Geographical Institute FEB RAS, Radio St. 7, Vladivostok, 690041, Russia \\ ${ }^{2}$ Potsdam University, Am Neuen Palais 10, 14469, Potsdam, Germany \\ ${ }^{3}$ St.-Petersburg State University, Universitetskaya nab., 7-9, St. Petersburg, 199034, Russia \\ ${ }^{4}$ Institute of Geography RAS, Staromonetniy pereulok 29, Moscow, 119017, Russia
}

\begin{abstract}
Investigations of the environmental changes on the Southern Kurils was based on multiproxy studies of sediments from several paleolakes. Stages of the lake development have been identified. Our study revealed climatic and palaeolandscape changes, ages and ecological effect of volcanic ash falls on Kunashir Island since the end of the Late Pleistocene, and manifestation of strong tsunami during the Middle to Late Holocene in Urup and Shikotan Islands.
\end{abstract}

Keywords: climatic changes, paleolandscapes, volcanic ash falls, paleotsunami

\section{Introduction}

Lakes of various origin, swamps and palaeolakes developed from overgrown lakes are widespread in the Kuril Islands. Their sediments provide an important source of information for environmental reconstructions (Lozhkin et al., 2017). Most of paleolakes on the Southern Kurils are located in coastal zone and represent by the final stages of the lagoons development, or were formed after severe storms in the mouths of small streams (Korotky et al., 2000; Nazarova et al., 2017). Lagoon development was controlled by sea level fluctuations and lithodynamic features. Paleolakes situated on higher relief forms usually underlain on the poorly permeable "parent" rocks and the origin of such palaeolakes is often related to volcanism. In our study we focus on response of ecosystems of the Southern Kurils to climatic changes and sea level fluctuations. We investigated vegetation history and reveal the natural catastrophic events recorded in lacustrine sequences.

\section{Materials and methods}

Reconstructions are based on multi-proxy approach, including lithogenic-facial study and biostratigraphic methods (diatom and pollen analyses). The depth-age models are based on radiocarbon dating and tephrostratigraphy. The identification of tephras is based on volcanic glass microprobe analysis.

\section{Results and discussion}

A palaeolake in the south part of Kunashir Island at the foot in the Golovnin Volcano was formed ca.13.914.2 ka BP. There are 12 tephra layers of Kunashir and Hokkaido volcanoes in the sediment section. Diatom analysis revealed 14 stages in the lake evolution. The lake began to form in a boggy area near a small stream after a large tephra deposition (up to $20 \mathrm{~cm}$ thick). Initially, planktonic diatoms (Aulacoseira italica, A. crenulata, A. alpigena) alongside with typical for shallow lakes epiphytes prevailed (up to $81 \%$ ). Several stages of high and low water stand were documented inferred from the diatom record. The unveiled short-term climatic fluctuations, in particularly moisture availability, well correlated with regional pattern of moisture. Lake shallowing was coincided with short-term coolings and related with reduced of precipitations. The lake existed up to the beginning of the cooling at 2.9-2.6 ka and developed into swamp after that. Several wetter and drier stages of swamp development up to the activation of soil formation have been identified. The stronger steam influence on the lake was recorded during the Medieval Warm Period.

At the end of the Late Pleistocene large areas were occupied by birch forests and Pinus pumila. Starting from a Pleistocene-Holocene transition and during the Early Holocene the role of conifers (especially Abies sachalinensis and Picea glehnii) sharply increased. In the Middle Holocene Alnus and Duschekia were widespread

*Corresponding author.

E-mail address: nadyar@tig.dvo.ru (N.G. Razjigaeva) 
along the stream. The role of broadleaf trees in forests increased. Abies sachalinensis, Picea jezoensis, and Pinus pumila became abundant during the Little Ice Age.

We studied a sediment section from a paleolake formed at ca. $3660 \mathrm{cal}$. yr BP at the southern part of Urup Island. We assume that at the peak of transgression happened $c a .6800 \mathrm{cal}$. yr BP, there was a bay penetrated into the island up to $500 \mathrm{~m}$. We disclose 8 stages in the evolution of the paleolake. The higher stands of the lake level were related to warmings (3660-3590; 34503180; 2960-2840; 2410-2260 cal yr BP), shallowing coincided with short-term coolings (3590-3450; 3180$2960 ; 2840-2410 ; 2260-2150$ cal yr BP) and reduced precipitations. The moisture deficit recorded from $c a$. 240 cal yr BP could be caused by the rise of the peat bog surface above the groundwater table. The longest stage of the lake shallowing $\sim 2840-2410 \mathrm{cal}$ yr BP coincided with global cooling. A low (regressive) stand of the sea level is evidenced from the presence of lenses of eolian sands in the peat. The dunes were stabilized during warming episodes and paleosol was formed at $c a$. 2340-2260 cal yr BP. Forest vegetation at the beginning of the Late Holocene was more diverse than in the present. Trees, including broadleaf ones, persisted here since the Holocene Optimum. Nowadays they do not occur north of Iturup Island. Pinus pumila was common among shrubs. No volcanic ashfalls occur at this part of the island during 7400-2100 cal yr BP. Therefore the environmental evolution here was mostly controlled by the climate. Eruption in the north of Iturup Island at ca.2100-2300 cal yr BP had a greatest ecological impact: the south of Urup Island was covered by up to $30 \mathrm{~cm}$ thick tephra layer. Decrease of the pollen of $A B$ vegetation suggests disappearance of forest and shrub communities and expansion of pioneering NAB communities (Ericaceae and Selaginella selaginoides) above a new substrate. Broadleaf species disappeared completely during the Little Ice Age.

The lacustrine sediments include interlayers of tsunami sands corresponding to four strongest tsunami events over the last $3660 \mathrm{cal}$ yr BP. The horizontal runup of the waves exceeded $500 \mathrm{~m}$, and the height of the run-up was more than 5-10 m. These events lead to changes of the lake water $\mathrm{pH}$ and development of sand sheets, with pioneering plant communities.

A more detailed record of the severe tsunamis that appeared in the south of Kurils is based on the study of the paleolake section (up to $5.6 \mathrm{~m}$ ) on the Malokurilskaya Bay coast (Shikotan Island). The lake was formed during the sea level rise at $c a .7240$ cal yr BP. Diatom assemblages recorded the lagoon succession to lake and swamp. At the initial stage of lake development at $c a$. 7240-6630 cal yr BP the conditions were close to lagoon and the climate was the warmest. Diatom flora included typical for well-warmed lagoons or closed bays Campylodiscus echeneis, C. clypeus, Achnanthes brevipes, and diverse and abundant species of the genus Tryblionella. When the sea level dropped at ca. 4900-4730 cal yr BP the inflow of sea water into the lake was minimal. The increase of arctoboreal and boreal freshwater diatoms indicated a decrease in water temperature. In the Late Holocene, the lake transformed into swamp. The sediments include two tephra layers of Tyatya Volcano and two ashes of Tarumai and Mashu volcanoes (Hokkaido). Deposits of 2 historical and 13 paleotsunami have been found.

\section{Conclusions}

1. The first and the longest (ca. $14.3 \mathrm{ka}$ ) records of palaeogeographic events in South Kurils demonstrated that useful palaeoenvironmental information resides in the sequences of small paleolakes.

2. Small-amplitude climatic changes of 140-430 year periods have been recognized in the Late Holocene in the Southern Kurils for the first time.

3. The ages of volcanic ashfalls and their environmental effects were identified.

4. Paleotsunamies on Urup Island are related to earthquakes that took place close to the island or south of it. On Shikotan Island the recurrence of large tsunamis that left sand sheets were less common on South Kuril Strait coast than on the Pacific side. The lake microflora showed response to the marine water inputs.

\section{Acknowledgments}

We thank all colleagues who helped us during the fieldwork. This study was supported by the Program of Priority Scientific Research FEB RAS, Project 18-5-003; LN was supported by the Deutsche Forschungsgemeinschaft (DFG) Project NA 760/5-1 and DI 655/9-1.

\section{References}

Korotky A.M., Razjigaeva N.G., Grebennikova T.A. et al. 2000. Middle and late-Holocene environments and vegetation history of Kunashir Island, Kurile Islands, northwestern Pacific. Holocene 10: 311-331.

Lozhkin A., Minyuk P., Cherepanova M. et al. 2017. Holocene environments of central Iturup Island, southern Kuril archipelago, Russian Far East. Quaternary Research 88: 23-38.

Nazarova L., Grebennikova T.A., Razjigaeva N.G. et al. 2017. Reconstruction of Holocene environmental changes in Southern Kurils (North-Western Pacific) based on palaeolake sediment proxies from Shikotan Island. Global and Planetary Change 159: 25-36. 